markings of Sigillariæ, longitudinal flutings and the usual leafscars, stigmarian roots and rootlets attached, \&c., others not so well preserved, being of doubtful affinities. Of course they are now but casts, nothing remaining of the original trees except a thin film of coaly matter representing the bark. They measure in height from three to ten feet, and have a diameter of from one foot to two feet four inches. I think it may be safely stated that they were merely hollow stumps when finally submerged, fronds of ferns, lepidodendroid twigs and leaves, and other vegetable waifs having found their way into the hollow cylinders and left their impress on the inclosed matrix.

I may add that there are several horizons of growth, one forest having grown above another; stigmarian roots and rootlets, calamites, lepidodendroid stems and leaves, lepidostrobi, and masses of leaves of unascertained species being indiscriminately mixed throughout the whole section, the ferns, however, being met with in greatest numbers near the bases of the erect trees.

It is perhaps worthy of remark, too, that there is no accumu lation of coaly matter in the section revealed, nor is there any of the usual "floor clay" about the roots of the trees.

29, Radcliffe Street, Oldham

JAS. NIELD

\section{Fungus Inoculation for Insects}

THE importance attributed by Dr. Lankester (NATURE, vol. xxi. p. 448) to “'Prof, Metschnikoff's suggestion of a deliberate cultivation of an insect's-disease-producing fungus, and the application of the cultivated fungus in quantity to places infested by these insects," invites attention to the fact that the suggestion has been anticipated in a very serious and earnest way by my friend the distingui:hed entomologist, Dr. John L. Le Conte of Philadelphia, in his presidential address before the Portland metting of the American Association for the Advancement of Science, in August, 1873.

His address concluded with ten suggestions for the promotion of economic entomology in the United States, and the seventh reads thus :- "Careful study of epidemic diseases of insects, especially those of a fungoid nature; and experiments on the most effective means of introducing and commuricating such diseases at pleasure."

The reasons for making this suggestion are fully stated in the preceding paragraphs of the address, where the observations on which it is based are detailed.

Dr. Le Conte's first suggestion was, "Reorganisation of the Department of Agriculture [at Washington] on a scientific basis, for the proper protection and advancement of agricultural interests." Had this suggestion received the attention which has been given to many other subjects of less practical importance, the present reciamation for him of priority in the case of his seventh suggestion, would probably have been rendered unnecessary; and the credit of introducing a more reasonable method of extirpating insect.pests than the dangerous plan of distributing potent mineral poisons to careless or uneducated persons for use in the fields, would have been secured to the nation to which we have the honour to belong.

Dr. Le Conte's address may be found in the publi-hed volume of the Proceedings of the Portland meeting; but it was reprinted by him and extensively circulated and favourably commented upon at the time, his desire being precisely that so well expressed by Dr. Lankester "to do something to persuade "practical' men that all science is deserving of their respect and encouragement." We all hoped that such earnest words from so high an authority would have their due effect upon Congress and inaugurate a long-desired reform of our Agricultural Burean. But it has happened, as in so many other instances, that we have had to wait seven years before even an echo reaches us from a distant part of the world, where the labours of Prof. Metschnikoff have procured an intelligent appreciation of the value of Dr. Le Conte's suggestion, so little comprehended by the powers at home.

I,008, Clinton Street, Philadelphia, April Io

\section{Carnivorous Wasps}

A SERIES of letters, under the above heading, kave appeared in NATURE for several weeks past. The facts they contain, although interesting in themselves, are nothing new to entomologists. That иа'ps are carnivorous, that they cha e flies, \&c., was known long ago (compare Westwood's "Introd. to Entomol.," ii. p. 246). That wasps cut off the wings of flies before sucking them was observed by Dr. Erasmus Darwin in the last century (see J. H. Fabre, "Souvenirs Entomologiques," Paris, 1879).

Heidelberg, Germany, May 6 AN OLD ENTOMOLOGIST

\section{Seeing by Telegraphy}

We beg to thank Mr. Gordon for drawing attention to the fact that the principle of rotation of plane of polarisation of light in a magnetic field could not actually be employed with the form of receiver symbolically described by us in NATURE, vol. xxi. p. 589. Having satisfied ourselves that there could be no doubt of the feasibility of using the first form of apparatus, which we spoke of, as a receiver in a sight telegraph, we merely wished to point out, at the end of our letter, that other methods might perhaps be employed; and we still have no doubt that with a certain proper arrangement of the apparatus not only the effects observed by Dr. Kerr, but other of the Faraday polarisation of light effects might be practically made use of. For it must be remembered that the actual electric currents now used to transmit articulate speech are only one forty-millionth per cent. as strong as those necessary to work even a delicate telegraph relay, whereas it required several Grove's cells to show in a decided way the old experiment of the sound emitted by an iron bar on being magnetised.

And in fact we may go further, and mention that we bave for the last year, or more, held the view that just as all electric conductors turn into heat energy a portion of the energy they transmit as electric current, so there must be some bodies, presumably of the sulphur selenium order, which, when properly employed, will convert a portion of the current energy into visible luminous vibrations, and may therefore be used as receivers in a sight telegraph.

As to the other objection that $\mathrm{mi}$ ht have been made to the method as popularly described by us in consequence of the large number of wires, we need hardly mention that in practice a telegraph engineer would avail himself of the principles of multiple telegraphy.

May 3

JOHN PERRY

W. E. AYrTon

\section{Anchor-Ice}

IN confirmation of Mr. Rae's views upon this subject, the following results of observations made upon the Charles River, Mass., may be of interest.

Anchor-ice is usually formed at night during a sudden "cold snap," when the river is not covered with surface-ice. It seems to consist of sma!1 masses of needle-like crystals grouped in stellate forms, and distributed pretty evenly throughout the body of water.

These adhere readily to any obstruction, and accumulate rapidly upon it. Thus the racks or strainers through which the water passes to the mills are covered and closed by it, so that the flow of the water is absolutely stopped, and the mills can only be kept running by constantly removing it with a rake.

It is very adhesive and tenacious. I have frequently seen it accumulate upon portions of the extreme edge of a mill dam (over which was pouring water a foot in depth) until it reached the surface, resisting for a con-iderable time the enormous pressure to which it was thus subjected. It usually disappears soon after sunrise.

Detached portions of the accumulated masses always rise to the surface, but the original crystals, if not heavier than water, seem to be at least as heavy. The general appearance of this ice when removed from the water re embles that of sherbet or "water ices." As these are frozen quickly while in motion, they are apparently formed under similar conditions. I have never seen anchor-ice txcept in rapid currents.

Boston, U.S.A., April 24

C. F. C.

Sodic Chloride Crystals. - Dr. Ord refers Dr. Ralton to Dr. Beale's book on " Kidney Diseases, Urinary Deposits, \&c.," ed. I869, p. I67, and the figure at p. 130; also Thudichum's "Pathology of the Urine."

Oxoniensis.-Apply to the Secretary, British Association, Albemarle Street, W. 